\title{
Cesta Svazu vynálezců do Národního technického muzea. Svaz vynálezců v Praze v letech 1920-1951
}

\author{
I VA N J A K B E C*
}

The Inventors Association and their Approach towards National Technical Museum. A Look at the Inventors Association in Prague during 1920-1951

\begin{abstract}
The paper is devoted to so far neglected and specifically focused Association - The Inventors Association in Prague. There was a desire by its members to present technical innovations and their own research and inventive activities to a wider public in form of exhibitions, licenses or patents. Thus, this was an example of modernization during first half of 20st century. At the same time, the Association developed into an unusually large membership base of several hundred members. Part of this paper is also an attempt to analyze the structure of the membership platform based on the fragmentarily preserved research sources. In many cases the members of the association held important positions within technical, administrative or managerial professions.
\end{abstract}

Keywords: The Inventors Association; Czechoslovakia; 20th century; National Technical Museum; modernization

DOI: $10.14712 / 23363525.2017 .24$

\section{Úvod}

Příspěvek je věnován ojediněle zaměřenému spolku - Svazu vynálezců v Praze a specifické skupině jeho členů. Ty spojovala touha po technických novinkách, vlastní výzkumná a vynálezecká činnost a možnost prezentovat své výsledky před širší veřejností na výstavách či formou patentů nebo licencí. Jedná se tedy o svého druhu příklad modernizace společnosti v první polovině 20. století. Současně spolek disponoval nebývale velkou členskou základnou o několika stech členech. Součástí příspěvku je také pokus o analýzu členské struktury z torzovitě zachovaných pramenů. Spolek vyjma předsednictva a členů výboru rozhodně nebyl omezen jen na Prahu či střední Čechy. Členové spolku zastávali v řadě př́padů významné posty v technické, administrativní a manažerské praxi. Hodí se rovněž dodat, že tomuto spolku dosud nebyla v české historiografii věnována pozornost.

Svaz vynálezců v Praze (od roku 1945 Ústřední svaz československých vynálezců a badatelů) patří bezesporu mezi spolky pozoruhodné svým zaměřením, poměrně širokým záběrem činnosti a nemalými ambicemi. O jeho významu v oblasti vynálezectví a patentové a licenční problematice svědčí nejen jeho úctyhodný počet členů, jeho kontakty s předními činiteli na národní úrovni (ministry, vysokými úředníky a významnými představiteli

Prof. PhDr. Ivan Jakubec, CSc., Ústav hospodářských a sociálních dějin, Filozofická fakulta Univerzity Karlovy, nám. J. Palacha 2, 11638 Praha 1. E-mail: ivan.jakubec@ff.cuni.cz. 
vědy, techniky a průmyslu), ale i kontakty se zahraničím. Svaz vynálezců překonal hospodářskou krizi počátku třicátých let i období protektorátu. Po roce 1945 spolek svoji činnost ještě zintenzívnil. Nakonec vplynul - do jisté míry logicky - do dnešního Národního technického muzea v Praze, nejprve jako součást spolku Technického musea a nakonec jako jedna z jeho odborných skupin. ${ }^{1}$ Oznámení o tzv. rozejití spolku bylo pak publikováno v Úředním listě II, č. 86, 13. dubna $1951 .^{2}$

Svaz vynálezců patřil mezi velké zájmové organizace díky počtu několika set členů (v roce 1926 měl již 1000 členů), až na výjimky s individuálním členstvím. Potýkal se však s nedostatečným kapitálem, resp. nepř́liš velkou příspěvkovou morálkou členů a předplatitelů spolkového periodika Práce a vynálezy a řečeno dnešním jazykem s nedostatkem štědrosti sponzorů. Paradoxně a možná překvapivě byl největším sponzorem Svazu vynálezců prezident T. G. Masaryk. Je také třeba objektivně konstatovat, že záběr činnosti spolku byl velmi široký a byl by náročný i pro státní instituci. Také jeho poradenská a zprostředkovatelská role pro vynálezce a badatele byla velmi rozsáhlá. Svaz vynálezců informoval o výstavách v Praze, Československu, Evropě i USA. Měl svůj samostatný výstavní stánek na pražském Výstavišti a nakonec i v prestižním Veletržním paláci v Praze.

V zahraničí vznikaly obdobné instituce zaměřené na podporu průmyslového bádání, avšak s podstatnou pomocí státu a soukromého kapitálu. Např. Jules-Louis Breton založil Office national des recherches scientifiques et industrielles et des inventions, v roce 1938 transformovaný v Centre national de la recherche scientifique appliquée v Bellevue u Paříže. Ve Velké Británii vznikl Departement of Scientific and Research, obdobně v britských dominiích a v Britské Indii. I v dalších státech vznikaly takto zaměřené instituce: v USA National Research Commitee, v Itálii Consiglio nazionale di Ricerche a v Belgii Office de Recherches industrielles. ${ }^{3}$

Zachované archivní materiály Svazu vynálezců jsou více méně torzovitého charakteru (za Pražského povstání byla zničena většina knihovny a archiv a další dokumenty ${ }^{4}$ ). Nejkompaktnější soubor dokumentů se nalézá ve Spolkovém katastru v Archivu hlavního města Prahy pro období 1920-1950 (0,1bm) ${ }^{5}$. V Archivu Národního technického muzea se zachoval fond Ústřední svaz československých vynálezců a badatelů, Praha o rozsahu 0,3 bm pro období 1929-1951. ${ }^{6}$ Zcela výjimečně jsou některé dokumenty z činnosti Svazu vynálezců zachovány v jiných fondech (např. Národní archiv, fond Presidium ministerské rady a Ministerstvo průmyslu, obchodu a živností; Státní oblastní archiv Praha, fond Obchodní a živnostenská komora v Praze). O činnosti Svazu vynálezců a jeho problémech se také dozvídáme z jeho kmenového časopisu Práce a vynálezy.

1 Př́íspěvek vznikl v rámci Programu rozvoje vědních oblastí na Univerzitě Karlově (PRVOUK) č. 12 Historie v interdisciplinární perspektivě, podprogram Evropa a (versus) svět: Interkontinentální a vnitrokontinentální politické, ekonomické, sociální, kulturní a intelektuální transfery.

2 Archiv hl. m. Prahy (dále jen AMP), f. Spolkový katastr (dále jen SK), sign. VIII/411, k. 285, čj. 262 560/9 1951.

3 [Štěpánek 1920-1921: 1-4].

4 [Akce pro zabezpečení našich vynálezců a badatelů 1946: obálka]. K 1. 7. 1943 disponoval spolek 88 publikacemi. AMP, f. SK, sign. VIII/411, k. 285, čj. 17411/1943.

5 AMP, f. SK, sign. VIII/411, k. 285. <http://amp.bach.cz/pragapublica/permalink?xid=ED0A32EF2D3411E0823D 00166F1163D4\&scan $=1>$ [7. 8. 2015].

6 [Honzáková 1972: 1]. 


\section{Spolek a jeho činnost v období 1920-1938}

Svaz vynálezců působil v samém centru Prahy (Václavské náměstí č. 53, od roku 1941 na stejném náměstí v č. $45 \mathrm{v}$ domě později zničeném za Pražského povstání, dnes hotel Jalta, poté v Mezibranské $21^{7}$ ). Byl velmi aktivní. Měl vlastní nakladatelství - Svět vynálezců (Václavské náměstí 53) - a vydával několik periodik.

Sám svaz odvozoval své snahy od neúspěšného předválečného pokusu Ing. Gustava Victora Fingera o zrrízení Patentního spolku a Svépomocného družstva vynálezců. Na podzim 1919 vznikl Svaz vynálezců, ${ }^{8}$ první stanovy byly přijaty v roce 1920. Svaz vynálezců se snažil usnadnit činnost vynálezců jejich hmotnou i odbornou podporou. Byl založen jako „jediné směrodatné ústředí vynálezců a badatelů, v poměrech poválečných, národohospodářsky neupravených, za účelem podporování vynálezectví v celé republice“ $9{ }^{9}$ Věnoval se tedy poradenské a konzultační činnosti, popularizaci a vydávání technicky zaměřených publikací, jako např̀ od L. Špirka Sbirka di̊ležitých rozhodnutí ve věcech patentových (Praha 1933) či od R. H. Rangera Král elektronů (Praha 1923). ${ }^{10}$

Na obálce vůbec prvního čísla spolkového časopisu Práce a vynálezy jsou uvedeny důvody založení Svazu vynálezců: nedostatečně propracovaný návrh patentu, neodborné řešení, nedostatečný kontakt vynálezce s odborníky a zájemci o vynález a potíže finanční a patentní. „Příčiny ty, které už před léty vedly v cizině vynálezce $\mathrm{k}$ sdružení se ve svazy, které by chránily jejich zájmy a napomáhaly jim k upravení cesty od dobrého nápadu, vynálezu k patentu a jeho zužitkování a finančnímu výtěžku, byly i pohnutkou k založení svazu na ustavující valné hromadě 1 . února t. r. "11 Ustavující valná hromada svazu se tedy konala 1. února 1920. Zemská správa politická v Praze 24. dubna 1920 nezakázala utvoření spolku. ${ }^{12}$ Podle zápisu ve Spolkovém katastru byl spolek ustaven dne 11. července $1920 .{ }^{13}$

Podle prvních stanov Svazu vynálezců z roku 1920 se jednalo o celorepublikový svaz s jednacími jazyky češtinou a slovenštinou a s „každou kulturní řečí jako dorozumívacím jazykem. Podle čl. V bylo účelem spolku „a) soustřediti práce vynálezců, poskytnouti jim bez rozdílu duševní i hmotné pomoci, též po stránce technického provedení, k uskutečnění vynálezu, resp. myšlének neb jich v principu směřujících, b) chrániti vynálezce před nezdarem a hmotnými ztrátami, c) řešiti problémy vlastní i objednané od zájemníků, d) poskytnouti členům nemajetným zvláštních výhod, e) zjednávati Svazu a členům patentní a vzorkovou ochranu doma i v cizině, tuto udržovati, hájiti jejich zájmy a práva ve všech směrech, f) pěstovati a udržovati stále styky s činnými vědeckými pracovníky a vynálezci, šiřiti vzdělání a podnikavost, povzbuzovati bádání a tvořivost

7 [Nová adresa Svazu vynálezců 1945: 31]; [Akce pro zabezpečení našich vynálezců a badatelů 1946: obálka].

8 [Štěpánek 1921-1922: 24].

9 Národní archiv Praha (dále jen NA Praha), f. Ministerstvo průmyslu, obchodu a živností (dále jen MPOŽ), k. 1013, čj. 114779/36 priora 71946/36.

10 [Tamtéž $]$.

11 [Práce a vynálezy 1920-1921: obálka].

12 AMP, f. SK, sign. VIII/411, k. 285, čj. 8-A 1334/1920.

13 AMP, f. SK, sign. VIII/411 <http://amp.bach.cz/pragapublica/permalink?xid=ED0A32EF2D3411E0823D00166F 1163D4\&scan=1> [7. 8. 2015], čj. 11601 s II. Ještě předtím bylo ustavení spolku povoleno výnosem zemské správy politické ze dne 24. ledna 1920 čj. 8A-1334-43 106 (7250 S II) [Tamtéž]. 
mezi členstvem i mimo svaz, g) uplatniti a využíti vynálezy se stanoviska hospodářského, živnostensko-průmyslového a obchodního“. ${ }^{14}$ Jako prostředky k dosažení účelu stanovy uváděly (čl. VI): „a) Získáváním členů, udržováním stálých styků s nimi. b) Poučováním, prozkoumáváním určitých případů a prováděním veškerých manipulací vynálezů se týkajících v mezích možnosti. c) Pořádáním přednášek, rozprav a exkurzí, sjezdů a výstav, vypisováním soutěží, udělováním odměn a vyznamenání. Zřízením vlastní knihovny, čítárny, odboček a vydáváním vlastní literatury. d) Sjednáváním licencí a prodeje práv z vynálezů, zakládáním podniků obchodních, výrobních a peněžních, zhotovováním plánů a rozpočtů, navrhováním smluv atd. e) Jměním svazu, příspěvky členů, dary a př́ijmy z činnosti svazu vyplývajícími. h) Odbory a společnostmi, řízenými zvláštními řády, valnou hromadou schválenými."15

Členství fyzických i právnických osob ve svazu (čl. VII) zabezpečoval minimální vklad ve výši 100 Kč (20 Kč zápisné a 80 Kč roční př́íspěvek). Členové byli čestní (zásluhy o svaz), zakládající („povinný“ vklad minimálně 5000 Kč), přispívající (100 Kč), činní (zápisné 100 Kč a 60 Kč ročně) a členové středu (funkcionáři a aktivní činní, ročně 60 Kč). ${ }^{16}$ Orgány svazu (čl. XI) tvořila valná hromada a výbor, revizoři. ${ }^{17}$ Působnost valné hromady (čl. XII) zahrnovala volbu předsedy, místopředsedy, jednatele, pokladníka, účetního, 6 členů výboru, 3 náhradníky a 2 revizory na dva roky. Podle čl. XVII spolek zanikl, pokud bylo méně než šest členů středu nebo se pro to vyslovily $3 / 4$ členů stř̌edu. Odkaz měla v př́padě zániku získat Masarykova akademie práce. ${ }^{18}$

Dne 6. května 1922 požádal spolek o změnu stanov. Podle strojopisu Stanovy Svazu vynálezců v Praze v čl. III se omezila jeho působnost na Čechy, na Moravu a Slezsko. V čl. XII o působnosti valné hromady došlo ke změně: kromě předsedy se volili dva místopředsedové, jednatel, pokladník, účetní, 10 členů výboru, 3 náhradníci, 2 revizoři na dobu dvou správních roků. ${ }^{19}$

Ani další změnu stanov spolku zemská správa politická dne 16. února 1927 (č. 181521/1926) „nezapověděla““ ${ }^{20}$ Dne 11. července 1930 spolek požádal o novou změnu stanov dle usnesení valné hromady 1. června 1930. Celkem rozsáhlé změny se týkaly řady článků. $\mathrm{V}$ některém případě byly jistě ovlivněny spory či připomínkami $\mathrm{k}$ hospodaření spolku (viz níže). Působnost spolku se vrátila k celorepublikovému působení (čl. III). Došlo ke zjednodušení čl. V o účelu svazu, k rozšíření prostředků k dosažení účelu (čl. VI. e ${ }^{21}$, g, h), čl. XIII. f) o zastupování svazu, čl. XV. o sporech členů a vložení nového čl. XVI. o přebytku hospodaření vložitelném do fondu. ${ }^{22}$ Výměr ministerstva vnitra z 20. září 1930 č. 48 848/1930 nezamítl tuto změnu stanov. ${ }^{23}$

\footnotetext{
14 AMP, f. SK, sign. VIII/411, k. 285, čj. 7250/1920, Stanovy Svazu vynálezců, rkp.: 1.

15 [Tamtéž, rkp: 2].

16 [Tamtéž, rkp: 2-3].

17 [Tamtéž, rkp.: 4].

18 [Tamtéż, rkp.: 7].

19 AMP, f. SK, sign. VIII/411, k. 285, čj. 16802/1922, Stanovy Svazu vynálezců, rkp.

20 AMP, f. SK, sign. VIII/411, k. 285, čj. 5003/1927.

21 VI. e) „zakládání dílen a laboratoří pro zhotovování modelů a vynálezů, zakládání podniků pro výrobu předmětů vynálezů a novinek, zužitkování výrobních postupů, zakládání pokladen pro poskytování záloh jen členům“. AMP, f. SK, sign. VIII/411, k. 285, čj. 20925/1930, Stanovy svazu vynálezců v Praze, s. 5.

22 [Tamtéž].

23 [Tamtéż].
} 
Podle Stanov Svazu vynálezců z roku 1937 došlo jen k dílčím změnám. ${ }^{24} \mathrm{~K}$ minimální změně došlo v čl. VII), který se týkal členství. ${ }^{25}$ Stanovy uváděly ještě, že dne 5 . prosince 1937 valná hromada snížila členské příspěvky na 60 Kč v prvním roce, 40 Kč v druhém roce a 20 Kč ve třetím a dalším roce. ${ }^{26}$

Z výčtu účelů spolku podle stanov jsou zřetelné velké, až obtížně naplnitelné ambice. Nemajetným výzkumníkům se nabízely blíže nespecifikované výhody. Činnost svazu zabezpečoval odbor patentový (Ing. Jaromír Grünwald, později Vojtěch Kapella ${ }^{27}$ ), technický (odborníci - členové svazu a vysokoškolští a středoškolští odborníci), právní (Dr. Vilém Kloubek, rada Zemského soudu v Praze) a redakční. Svaz oznamoval spolupráci s obdobnými zahraničními společnostmi v USA, Velké Británii, Francii. Později, od poloviny třicátých let byly odbory modifikovány na patentový, hospodářský, propagační, zpeněžovací a časopisový.

Podívejme se nyní na složení prvního předsednictva svazu v roce 1920. Předsedou byl Dr. Ing. František Kňourek, báňský rada v ministerstvu veřejných prací; jeho místopředsedou Rudolf Šimonek, továrník; tajemníkem byl Ing. L. Karnet, vrchní komisař rumunských státních drah ve výslužbě a patentní poradce; jednatelem byl Ing. František Štěpánek; pokladníkem byl Karel Sochor, major v ministerstvu národní obrany; jako účetní působil Vladimír Minichbauer, vrchní účetní. Členy výboru byli Ing. Karnet, Vilém Kloubek, rada Zemského soudu v Praze, Bedřich Krátký, Ladislav Svoboda, rýsovač, František Šimana, stavitel na Smíchově a Ing. Jaroslav Veselý, ředitel Technického musea. ${ }^{28}$

Svaz usiloval o těsnější spolupráci s Jednotou Přátel Masarykovy akademie práce, resp. o své přičlenění. Od možného přxičlenění si svaz sliboval podporu vládních kruhů, stejně jako od vysokých státních ministerských úředníků. Je faktem, že sekční šéf ministerstva veřejných prací, Ing. Emil Zimmler, ${ }^{29}$ navštívil jednu $\mathrm{z}$ valných hromad svazu a přislíbil podporu. ${ }^{30}$ Úsilí o získání dárců, dnešním jazykem sponzorů, vůbec nebylo úspěšné. Velké finanční domy odmítly, jen Banka československých legií poskytla 5000 Kč a Živnostenská banka darovala 100 Kč, které „svaz odmítl s poznámkou, že nepřijímá almužen“. ${ }^{31}$ Svaz apeloval na upisování pro dobro vlasti. Dokonce se objevil možná až překvapivě ostrý protiněmecký osten: „Př́šśí boj s Německem bude bojem daleko těžším, bude bojem technicko-hospodářským. Protož připravme se na něj racionelní podporou našich nadaných lidí, nebot tím získáme všichni. “32

V roce 1921 uváděl svaz již na 350 členů a vykazoval 521 podaných patentových přihlášek, ochranných vzorů a známek a množství již udělených patentů, které zprostředkoval. ${ }^{33}$

\footnotetext{
24 NA Praha, f. MPOŽ, k. 1013, čj. 71946/36, Stanovy Svazu vynálezců v Praze, s. 3-4; Archiv Národního technického muzea Praha (dále jen NTM Praha), f. Ústřední československých vynálezců a badatelů, k. 1, Stanovy svazu vynálezců v Praze. Založeno r. 1920, Praha 1937. Dodatek Usnesení valné hromady Svazu vynálezců z 5. prosince 1937 .

25 NA Praha, f. MPOŽ, k. 1013, čj. 71946/36, Stanovy Svazu vynálezců v Praze, s. 6-7; ANTM Praha, f. Ústř̌ední československých vynálezců a badatelů, k. 1, Stanovy Svazu vynálezců v Praze.

26 [Tamtéž, s. 16].

27 Změnu uvádí druhý ročník.

28 AMP, f. SK, sign. VIII/411, k. 285, čj. 11 601/1920 a 10 757/1920.

29 Významný český vodohospodár. Naposledy vyšly jeho paměti [Zimmler 2013].

30 Datum valné hromady není specifikováno [Práce a vynálezy 1920-1921: obálka].

31 [Tamtéž].

32 [Tamtéž].

33 [Štěpánek 1921-1922: 24].
} 
Mezi nejvýznamnější podporovatele patřil americký Čech J. B. Drahoňovský (5000 Kč). Ani podnikatelé nebyli př́liš štědří. Mezi výjimky patřila firma Inž. J. Podhajský, továrny ventilátorů $\mathrm{v}$ Uhříněvsi, která věnovala brousící stroj, a jeden německý nejmenovaný podnik, který poskytl zařízení za $40000 \mathrm{Kč}$. Svaz usiloval o vhodná místa pro laboratoře a dílny u pražského magistrátu. Svaz dále neúspěšně usiloval o získání licencí pro tři biografy v Praze. Jako nejštědřejším se ukázal prezident T. G. Masaryk, který z Masarykova národního fondu poskytl 50000 Kč pro nově vzniklý fond svazu - Fond pro nemajetné vynálezce. Tisícikorunou do něho také přispěl účetní svazu V. Minichbauer. ${ }^{34}$

O významu spolku svědčí nejen místa konání, valných hromad, ale i přítomní hosté a odborná náplň. Dne 23. listopadu 1922 se konala valná hromada svazu. Byla pojata velkoryse. Konala se v sídle obchodní a živnostenské komory v Praze za účasti poslaneckých klubů, ministerstev, Patentního úřadu, obchodních a živnostenských komor, Inženýrské komory, různých grémií, Svazu průmyslníků, Technického musea aj. Námětem byla problematika patentové ochrany (referent Ing. Karel Pavel z Brna, diskutující např. Adolf Stejskal, Ing. Bečka - z Klubu národní demokracie, Dr. Ing. Vojáček, Ing. Pavlousek viceprezident Patentního úřadu) a zvýšení poplatků za úkony Patentním úřadem (referent Karel Malva Pokorný). ${ }^{35}$ Čestnými předsedy spolku se stali 27 . února 1924 ministr průmyslu, obchodu a živností Ing. Ladislav Novák a vrchní báňský rada Dr. Ing. František Kaňourek. ${ }^{36}$

Svaz usiloval o zřízení svého Fondu pro zužitkování vynálezů, což se mu podařilo na konci roku 1924. V podstatě pravidelně se zúčastňoval jarního a podzimního veletrhu a dalších výstav (např. hospodářských) v Praze. Svaz zprostředkovával pro své členy výstavní místa na vzorkových veletrzích v Průmyslovém paláci a na jaře 1925 si otevřel vlastní expozici - stánek před Průmyslovým palácem. Zprávy v časopisu označovaly výstavní činnost za úspěšnou. V roce 1926 vyzýval svaz své členy, aby se zúčastnili mezinárodní výstavy v americké Filadelfii. V témže roce dosáhl počet členů svazu jednoho tisíce.

Na rok 1927 avizoval svaz účast členům v Bruselu a ve Vídni. V roce 1928 byl představen záměr na zřízení stálé expozice svazu v budově Pražských vzorkových veletrhů (Veletržní palác), což se uskutečnilo roku 1929, v prvním poschodí. Stále však několik míst ve výstavním prostoru zůstalo prázdných, jak o tom svědčí neustále se opakující inzeráty na obsazení. Svaz vynálezců zasahoval do širších diskusí, např̀. ohledně patentové ochrany, licenční a př́ibuzné problematiky. V polovině dvacátých let některé státy (např̀. Německo) přešly na delší než 15leté období ochrany patentů. Svaz vynálezců např̀. požadoval v roce 1926 prodloužení ochrany patentů z dosavadních 15 let na dvojnásobek. Odůvodňoval to dobou pro zavedení do praxe. ${ }^{37}$

Svaz sám pořádal přednášky a jeho členové se zúčastňovali řady akcí aktivně či pasivně. Z přednášejících uved’me z roku 1933 odborníka na patentové právo doc. Ing. L. Špirka. Svaz vynálezců požádal v roce 1936 o státní př́íspěvek ve výši 500000 Kč na založení vlastních výrobních podniků, na zařízení dílen, na pořádání mezinárodní výstavy v roce 1937 a na obnovení vydavatelské činnosti. Nepřekvapí, že žádosti soukromého subjektu

34 [Tamtéž: 25].

35 [Schůze vynálezců a majetníki patentů 1922-1923: 97-98].

36 AMP, f. SK, sign. VIII/411, k. 285, čj. 5077/1924.

${ }^{37}$ Státní oblastní archiv Praha (dále jen SOA Praha), f. Obchodní a živnostenská komora Praha (dále jen OŽK Praha), k. 775, sl. VI/1/14, čj. 41172/1926. 
o podporu tak rozsáhlé činnosti ministerstvo průmyslu, obchodu a živností ani vyhovět nemohlo. Přesto Svaz vynálezců uspořádal pod záštitou ministra průmyslu, obchodu a živností Josefa Václava Najmana v roce 1936 v Praze na ČVUT I. výstavu vynálezů. ${ }^{38}$

Styky se zahraničím, zejména s Německem, dokládá ojedinělý dochovaný dokument. Dne 24. července 1935 se obrátil Ing. Wilhelm Heberer z Frankfurtu nad Mohanem na německé vyslanectví v Praze se stížností, že již 22. června a 2. července zaslal na patentní kancelář Svazu vynálezců dvě patentové přihlášky - vysoce citlivého relé firmy Wemac G.m.b.H. (Frankfurt nad Mohanem-Rödelheim) a postupu k zabránění tvorby ledu na povrchu živičné dlažby Willi Seiler/Gebrüder Weil (Baugeschäft in Limburg a.d. Lahn) a dosud však nedostal žádnou odpověd'. Svazu vynálezců byl v této souvislosti adresován dopis obchodního oddělení pražského německého vyslanectví z 27. července. O dva dny později konečně Svaz vynálezců odpověděl pražskému vyslanectví, že podklady přeložil a předal Patentovému úřadu a zaslal kopie podkladů a potvrzení firmě Wilhelm Heberer. K prodlení došlo v důsledku čerpání dovolené příslušného zaměstnance a obtížnosti překladu přihlášek. ${ }^{39}$

$\mathrm{V}$ meziválečném období se ve funkci předsedy vystřídali Dr. Ing. František Kňourek, báňský rada v ministerstvu veřejných prací (1920-1922), Rudolf Šimonek, obchodník (1922-1924), Josef Štekl, správce cihlářských závodů v Sedlci (Praha-Sedlec) (1924-1937) a Jan Pavlečka, ředitel školy v. v. (1937-1940). Ve funkci 1. místopředsedy působili Rudolf Šimonek (1920-1922), Ing. František Štěpánek (1922-1924), Ing. Václav Pelnař, majitel chemické továrny (1924-1932), arch. Václav Kvasnička (1932-1935), Karel Loquens (1935-1937), Hubert Hejtman, řídící školy v. v. (1937-1938), Bedřich Landa (1938-1940) a ve funkci 2. místopředsedy Ing. Karnet (jako tajemník, 1920-1922) a MUDr. Šebestián Hněvkovský (1922-1940).

Nahlédnutí do vnitřního fungování spolku není prríliš jednoduché vzhledem $\mathrm{k}$ torzu zachovaných materiálů. Pravděpodobně první stížnost se objevila již po první valné hromadě. Na zemskou politickou správu uskutečnil podání dne 17. července 1920 Bedřich Krátký. Vadilo mu, že Ing. František Štěpánek byl navržen a zvolen za jednatele, ač byl ještě před valnou hromadou honorován jako redaktor časopisu 600 korunami měsíčně. V poznámce ve spise je uvedeno, že došlo ke smíru a stěžovatel zůstal ve výboru. ${ }^{40}$

Zemskému úřadu v Praze a Policejnímu ředitelství v Praze byl 28. února 1935 adresován požadavek spolku na vyslání příslušného úředníka k zajištění řádného chodu valné hromady 17. března 1935. Návrhy a protest opozice (22 podpisů) se týkaly údajně neúplného programu valné hromady a schválení členů středu před hlavními body schůze. ${ }^{41}$ Zajímavý je jiný anonymní podnět z 8 . ledna 1935, že spolek nic nedělá, jen vybírá poplatky a navrhuje mimořádnou revizi ve spolku, nebot si činovníci rozdělují peníze mezi sebe. Ve spisu je poznámka, že „stížnostmi uvedenými v této anonymní stížnosti není doložen veřejný zájem“. 42

38 NA Praha, f. Ministerstvo průmyslu, obchodu a živností (dále jen MPOŽ), k. 1013, čj. 114779/1936 priora 71946/1936.

39 Politisches Amt des Auswärtigen Amtes, Berlin, f. Prag, k. 236, čj. X/2bc/1935. Za upozornění děkuji Mgr. D. Hubenému (NA Praha).

40 AMP, f. SK, sign. VIII/411, k. 285, čj.11 040/1920.

41 AMP, f. SK, sign. VIII/411, k. 285, čj. 2 938/1935 a 7 681/1935.

42 AMP, f. SK, sign. VIII/411, k. 285, čj. 810/1935. 
Dne 21. března 1935 došla policejnímu ředitelství stížnost Petra Jodase jménem pětadvaceti členů spolku, že valná hromada spolku konaná dne 17 . března 1935 byla zmateční. Jednak prý byla odepřena přítomným členům volba členů „středu“, pokladníka Pavlíčka nezbavila členství valná hromada, nebyl dán dostatečný prostor se vyjádřit a ze sálu byl vyveden kriticky se vyjadřující Ing. Kapela. Policejní protokol ze dne 18. července 1935 s P. Jodasem uváděl, že stěžovatel uznal svoji stížnost vzhledem k stanovám za bezpředmětnou. ${ }^{43}$

Člen výboru Jan Benda podal 16. listopadu 1937 policejnímu ředitelství v Praze obsáhlé podání, kde uváděl, že předseda Jan Pavlečka nedodržuje stanovy o spolkovém jmění. Jednalo se mj. o odměny v září ve výši 950 Kč pro zaměstnance-nečleny spolku, dále o přesčasové odměny za srpen ve výši 941,55 Kč, za září 1742,20 Kč. Dalšími finančními aférami byla údajná zpronevěra 40000 Kč vedoucího úředníka spolku, údajně 10000 Kč dluhů na daních, údajně nesprávné vyúčtování dvou výstav atd. Podání podpořil podpisem H. Hejtman, první místopředseda. ${ }^{44}$ Protokol o výslechu J. Pavlečky ze dne 21. dubna 1939 uvedl Bendovy výhrady na pravou míru. Jen pro ilustraci, na daních dlužil svaz jen 2500 Kč. V policejním protokolu ze dne 25. dubna 1939 vzal J. Benda své podání zpět. ${ }^{45}$

\section{Vydavatelská činnost}

Svaz vynálezců prostřednictvím nakladatelství Svět vynálezců v Praze vydával periodikum Práce a vynálezy s podtitulem Populární sborník pro práci, vědu a vynálezy všech oborů. Odpovědným redaktorem byl Ing. František Štěpánek. První číslo vyšlo v prvním roce existence spolku, v roce 1920. Předpokládalo se, že časopis bude vycházet jednou za měsíc, př́padně podle zájmu dvakrát měsíčně. Časopis obsahoval dobově obvyklé rubriky: mj. novinky zaslané redakci, kromě toho také rubriky Články úvodní (zpravidla delší), články, Vševěd, Patentová hlídka, Rady a dotazy, Domácí dílna. Rubriky se každoročně obměňovaly.

Odpovědný redaktor F. Štěpánek již v prvním čísle uvedl, že „několik jen vynálezců sdružilo své úsilí a své vědomosti k podpoře druhých ve Svaz vynálezců, který během půl roku vzrostl v organisovanou humanní instituci, vyzbrojenou vlastní technickou kancelárí $\mathrm{k}$ provádění posudků, plánů, prezentace, $\mathrm{k}$ udílení porad, zaopatřování modelů a sprostř̌edkování prodeje nových vynálezư “ ${ }^{46}$ Od druhého ročníku vycházely Práce a vynálezy dvakrát měsíčně, a to na žádost abonentů.

Čtvrtý ročník časopisu přinesl zprávu o činnosti spolku od jeho jednatele J. E. Holana: „Časopis ,Práce a vynálezy“ co časopis spolkový přinášeti bude hlavně články a zprávy, zajímající nejen širší veřejnost $z$ kruhů průmyslových, obchodních a zemědělských, ale hlavně členy z kruhu vynálezců, vědců a badatelů, jakož i referáty o nových vynálezech všeobecných i členských. " ${ }^{77}$ Současně autor uvedl kritiku některých členů dosavadního vedení: „Z vedení svazu odešli někteří pp. členové, kteří bud’ funkcí svazových řádně nevykonávali,

\footnotetext{
43 AMP, f. SK, sign. VIII/411, k. 285, čj. 9 299/1935.

44 AMP, f. SK, sign. VIII/411, k. 285, čj. 24 530/1937.

45 AMP, f. SK, sign. VIII/411, k. 285, čj. 24 530/1937, protokol bez čj.

46 [Štěpánek 1920-1921: 17-18].

47 [Holan 1923-1924: 2].
} 
nebo byli jednak přímo, jednak nepř́mo akcím svazovým škodlivými. “48 Vybudování svazových dílen, o které spolek usiloval, se nepodařilo podle jednatele jednak $\mathrm{z}$ důvodů nedostatku financí na trhu, nedostatečného pochopení významu, jednak z hlediska osobního prospěchu nejmenovaného zodpovědného funkcionáře. ${ }^{49}$ Článek končí heslem „, práci a vědění, jest naše spasení. 50

Štěpánkovo působení v redakci časopisu Práce a vynálezy trvalo jen dva roky. Po útocích odstoupil a na jeho místo nastoupil na podzim 1922 Karel Malva Pokorný (od 3. ročníku). Štěpánkovi bylo údajně vytýkáno zaměření se hlavně na vlastní časopis Nová epocha. Dopis předsednictva končil slovy: „Naše svědomí jest klidné, milerádi komukoliv předložíme doklady. Doufáme, že se pan inž. Štěpánek bude míti na pozoru!“51

Od čtvrtého ročníku redigoval časopis Práce a vynálezy Ing. Vojtěch Kapella. Nakladatelství Svazu vynálezců vydávalo také samostatné publikace. V březnu 1924 vykazoval svaz 704 členů, přes 1000 přihlášek patentů a 600 udělených patentů ${ }^{52}$, což představovalo až jednu čtvrtinu všech patentů udělených v Československu. ${ }^{53}$ Od roku 1924 se časopis vrátil k měsíční periodicitě. Časopis vycházel nepravidelně, zejména v době hospodářské krize. Např. v letech 1931, 1933 a 1935 vyšla jen dvě čísla, v roce 1934 žádné ćíslo, naopak v roce 1932 čtyři čísla. V roce 1935 a 1936 ještě vyšla dvě speciální inzertní čísla. Časopis překonal potíže první poloviny třicátých let a vycházel ještě několik let po válce (1945 až 1949) a v roce 1950 byl sloučen s Objevy techniky a pokračoval až do roku 1967 jako Svět techniky. ${ }^{54}$

Dále Svaz vynálezců vydával čtrnáctidenní list Věž, který redigoval uvedený spisovatel Karel Malva Pokorný. Jednalo se o původní literární tvorbu, tedy o svého druhu vynálezy. ${ }^{55}$ Věž vycházela jen v letech 1921-1922. Dalším listem, který Svaz vynálezců založil, byla Radiohlídka. Na jedné straně lze ocenit povzbuzení zájmu o technické novinky, na druhou stranu vzhledem k finanční situaci svazu to nebylo př́liš strategické rozhodnutí. Vyšel jen jeden ročník 1922-1923. To samé platí o dalším počinu Patentní revue. Připomeňme, že časopis s obdobným název Patentní věstník vydával Patentní úřad.

\section{Aktivita spolku v období 1939-1945}

Spolek podáním z 2. května 1939 podle vládního nařízení č. 97/1939 Sb. ze dne 31. března 1939 oznámil, že bude vyvíjet činnost i nadále. ${ }^{56}$ To samé sdělil dne 27 . dubna 1939 pražskému policejnímu ředitelství. ${ }^{57}$ Následovala úprava stanov podle nařízení zemského prezidenta v Praze ze dne 29. prosince 1939 č. 77065 pres. ${ }^{58}$ Valná hromada 30. června

\footnotetext{
48 [Holan 1923-1924: 28].

49 [Tamtéž: 29].

50 [Tamtéž].

51 [Práce a vynálezy 1922-1923: obálka].

52 [Holan 1923-1924: 1-2].

53 [Patentní věstník 1921-1922].

54 AMP, f. SK, sign. VIII/411, <http://aleph.nkp.cz/F/JK8Q58SMPS9CNKQTVGE7MX4MPY62MLEY7EASH 286UNAMG8YNP5-49647?func $=$ full-set-set\&set_number $=047638 \&$ set_entry $=000002 \&$ format $=999 \#$ tail $>$ [cit. 23. 7. 2015].

55 [Práce a vynálezy 1920-1921: obálka].

56 AMP, f. SK, sign. VIII/411, k. 285, čj. 7773/1939.

57 AMP, f. SK, sign. VIII/411, k. 285, čj. 13966/1939.

58 AMP, f. SK, sign. VIII/411, k. 285, čj. 253/13 1940.
} 
1940 se usnesla na změně stanov, která byla potvrzena výnosem ze dne 12. listopadu 1941 čj. D-3111-21/3-1941-6. ${ }^{59}$ Protektorátní stanovy (strojopis) omezovaly působnost spolku na Protektorát Čechy a Moravu (čl. III), jednací řečí byla jen čeština (vypadla slovenština) a dorozumívací každá kulturní řeč (čl. IV), v XI. čl. rušily písmena b a c a rušily pojem užšího výboru. V článku o působnosti valné hromady (čl. XII) se zvýšil počet volených členů výboru: předseda, dva místopředsedové, jednatele, pokladníka, účetního, 16 členů správního výboru, 2 revizory bez uvedení délky mandátu. Mimořádnou valnou hromadu mohla nahradit výborem svolaná schůze členů středu nově charakterizovaných mj. jednoročním členstvím, kterému byly uděleny nejméně dva různé patenty, resp. jeden. Současně správní výbor volil (čl. XIII) druhého jednatele, knihovníka-archiváře a zapisovatele. Čl. XIX rušil spolek v př́ípadě, že by měl méně než 11 členů, přičemž jeho majetek by připadl České akademii technické (tedy bývalé Masarykově akademii práce) ${ }^{60}$ Paradoxně tyto stanovy zůstaly v platnosti až do zániku spolku (viz níže).

Za protektorátu funkci předsedy vykonával Jan Pavlečka, ředitel školy v. v. (od 1937 do rezignace a vyloučení 1940), Ing. Jaroslav Pavlát, vrchní technický rada hlavního města Prahy (1940-1942), Ing. Eduard Caha, majitel velkostatku, Brnky 1 (Roztoky), funkci nepřijal (1942) a zastupoval l. místopředseda Bedřich Landa, ředitel školy (1942-1943), Karel F. Kř́íž (od 1943 do rezignace 1947). Funkci 1. místopředsedy zastával Bedřich Landa, klavírní technik (1938-1942), Emil z Freyburgů (1943-1945) a 2. místopředsedy MUDr. Šebestián Hněvkovský (1922-1940), Ing. Arnošt Kasper, vrchní komisař (od 1940 do rezignace 1941), Jindřich Binar, technický úředník, (1942-1943) a Gustav Flosman (1943-1945).

Ani období protektorátu se neobešlo bez stížností členů na vedení spolku. Dne 30. června 1940 se obrátil na policejní ředitelství jako dohlédací úřad nad spolky bývalý předseda Jan Pavlečka a bývalý druhý místopředseda spolku, MUDr. Šebestián Hněvkovský, ohledně porušení stanov. Jednak se jednalo o vyloučení předsedy Jana Pavlečky a druhého místopředsedy Hněvkovského. Oba byli nařčeni výborem z „nečestných jednání“ kvưli tomu, že si dali vyplatit $1000 \mathrm{~K}$ od spolku, avšak to mělo být vrácení půjčky svazu. Současně bylo oběma zamezeno účastnit se valné hromady 30. června 1940. Údajně před Pavlečkovým předsednictvím se vyplácely odměny neschválené valnou hromadou. V protokole sepsaném na policejním ředitelství v Praze dne 9. července 1940 nově zvolený předseda spolku Ing. Jaroslav Pavlát vypověděl, že oba jmenovaní byli vyloučeni na výborové schůzi 18. června 1940 a následně to valná hromada 30. června schválila. Dne 11. června 1940 ohlásil J. Pavlečka rezignaci na předsednictví adresovanou Š. Hněvkovskému. Uvedl, že „tříletou intensivní činností podařilo se mi s pomocí Vaší, pana Rohana a také zaměstnanců kanceláře Svaz zachránit a sanovat. Byly dovedeny ku konci obtížné a nákladné spory soudní, zaplaceny dluhy a spláceny dlužné daně, odstraňovány nepořádky ve věcech členských, zahájena byla široká akce pro zlepšení naší ochrany patentové, jejíž vady a nedostatky těžce postihují naše vynálezce. Špatná pověst svazu se zlepšovala a důvěra členstva se zvyšovala."61 Výměrem policejního ředitelství ze dne 11. července 1940 se oportunisticky konstatovalo, že „ježto vylučování členů je vnitřní záležitostí spolkovou, do níž úřadům,

59 AMP, f. SK, sign. VIII/411, k. 285, čj. 253/13 1940 a čj.113/1942.

60 AMP, f. SK, sign. VIII/411, k. 285, Stanovy, sine čj.

61 AMP, f. SK, sign. VIII/411, k. 285, čj. 21 598/1940. 
vykonávajícím podle zákona spolkového dozor nad spolky, zasahovati nepřrísluší, odmítá policejní ředitelství dále jednati o uvedeném Vašem podání“ ${ }^{62}$ Proti tomuto rozhodnutí se 22. července J. Pavlečka odvolal k Zemskému úřadu v Praze. Policejní ředitelství svưj názor výnosem ze dne 6. srpna 1940 nezměnilo. ${ }^{63}$

Ve Spolkovém katastru nalezneme také podání Ing. Arnošta Kaspera, magistrátního úředníka ze dne 11. března 1941. V něm se jako 2. místopředseda spolku dožadoval prohlášení voleb z 30. června 1940 za zmatečné. „V zájmu urychlení vnitřních změn provedeny byly volby dle nově navržených stanov i s příslušným rozšířením výboru. Zodpovědní funkcionáři svazu, nově povelný předseda a jednatel, dali však několik dnů později nepřítomné ze zvolených členů z části vyškrtnouti a dohlédacím orgánům podali nesprávné hlášení, totiž dle počtu odpovídajícího stanovám starým. "64 O zřízeném Fondu na podporu vynálezců ve výši $5000 \mathrm{~K}$ nebylo údajně členstvu nic známo. Odměny prý odhlasoval výbor, nikoliv valná hromada dle stanov. ${ }^{65}$ Zaměstnanci prý neumí natolik německy, aby mohli překládat pomocí slovníku, využívají se drahé překladatelské služby, dokonce hrozí zcizení vynálezů. A podání končilo výhružně: „Žádám proto, aby činnost svazu až do provedení ŕádných voleb byla zastavena a o posouzení, nejde-li v daném případě o trestní čin. "66 Stížnost byla podle protokolu sepsaného na policejním ředitelství v Praze dne 24. března 1941 vzata zpět ${ }^{67}$ (21. března rezignoval na funkci místopředsedy). ${ }^{6}$

Z dalších několika mála zachovaných dokumentů z období protektorátu lze uvést dopis ze dne 3. prosince 1940, ve kterém Svaz vynálezců žádal předsedu protektorátní ministerské rady Ing. A. Eliáše o stálý prŕíspěvek svazu (podepsáni Ing. Arnošt Kasper a Ing. Jaroslav Pavlát). Svaz se v dopise odvolával na své podání ze dne 18. září 1940 na ministerstvo veřejných prací o poskytnutí prríspěvku „k úhradě zvýšených vydání Svazu a podpoře jeho všeužitečné činnosti“. 69 Svaz sdružoval okolo 600 vynálezců z území protektorátu. Vyšší výdaje vyplývající $z$ koncentrace patentové činnosti v berlínském Patentním úřadu se týkaly zvýšení přihlašovacích poplatků a tax, nárůstu vnitřní režie v důsledku nutnosti překladů a zvýšení vydání za modely v důsledku navýšených požadavků na jejich úpravu. „Proto nemůže Svaz nemajetným členům nadále poskytovati takovou podporu jako dříve, z čehož vzniká státu i Řiši zvýšená hospodářská škoda, nebot část vynálezců zůstává nepropracována, př́ípadně vůbec nevyužita." ${ }^{70} \mathrm{Z}$ připsání na dokumentu je zřejmé, že ministerstvo veřejných prací povolilo podporu ve výši 5000 Kč.

62 [Tamtéž].

63 AMP, f. SK, sign. VIII/411, k. 285, čj. 22 562/1940 priora 21 598/1940.

${ }^{64}$ AMP, f. SK, sign. VIII/411, k. 285, čj. 7250/1941, rkp. s. 1.

65 [Tamtéz: 2-3].

66 [Tamtéz: 3].

67 AMP, f. SK, sign. VIII/411, k. 285, čj. 7250/1941, Protokol sepsaný na policejním ředitelstvív Praze dne 24. března 1941, sine čj.

${ }^{68}$ AMP, f. SK, sign. VIII/411, k. 285, čj. 7250/1941.

69 NA Praha, f. Presidium ministerské rady (dále jen PMR), k. 1431, čj. 45523/40. Autor děkuje PhDr. D. Hubenému (NA Praha) za upozornění na tento dokument.

70 [Tamtéž $]$. 


\section{Závěrečné období let 1945-1951}

Krátce po osvobození bylo na mimořádné valné hromadě 5. srpna 1945 schváleno nové znění stanov, předložené na počátku září ke schválení ministerstvu vnitra a průmyslu. Název svazu nyní zněl Ústřední svaz československých vynálezců a badatelů. Dne 5. zárí 1945 Spolek oznámil, že předložil žádost ministerstvu vnitra o schválení stanov. ${ }^{71}$

Svaz vynálezců dopisem ze dne 17. zárí 1945, podepsaným prvním místopředsedou Antonínem Kasýkem a jednatelem Ing. Dr. F. Láskou, oznamoval změnu stanov, resp. výpisy ze zápisu o mimořádné valné hromadě Svazu vynálezců v Praze ze dne 5. srpna 1945, ze zápisu o schůzi správního výboru Svazu vynálezců v Praze ze dne 24. srpna 1945 a ze zápisu o schůzi správního výboru Svazu vynálezců v Praze ze dne 14. záŕí 1945. Posledně uvedený výpis uváděl, že v návrhu nových stanov předložených ministerstvu vnitra byly nově uvedeny fakultativní funkce - protektora a jeho náměstků a prezidenta a jeho náměstků. Proti těmto titulům se postavilo ministerstvo vnitra a místo prezidenta se uvažovalo o titulu čestný předseda. Výpis končí konstatováním, že funkce protektora bude vypuštěna a funkce prezidenta nahrazena čestným předsedou a že svaz je oprávněn zakládat odštěpné spolky s vlastními stanovami. ${ }^{72}$ Dne 9. záŕí 1946 svaz jménem úřadujícího místopředsedy Václava Kracíka a jednatele dr. Srby konstatoval, že ministerstvu vnitra (spolkového oddělení) již 5. září (listopadu přeškrtnuto) 1945 předložil změnu stanov včetně nového názvu spolku. A protože svaz nedostal kladné ani záporné stanovisko, bude napřriště užívat nový název Ústřední svaz československých vynálezců a badatelů. ${ }^{73}$

Dne 7. října 1945 se měla konat řádná valná hromada svazu, ale v důsledku neschválení stanov byla odložena na neurčito. ${ }^{74}$ Obdobně měla být svolána na 6. ř́jna $1946 .{ }^{75}$ Teprve až řádná valná hromada svolaná na 18. května 1947 se uskutečnila. ${ }^{76}$ Předsedou se stal Václav Hubač, prvním místopředsedou Jiří Janoušek, druhým místopředsedou František Loos, jednatelem JUDr. Václav Srba, pokladníkem K. M. Smolík a účetním Josef Lanzendörfer. ${ }^{77}$ Zpráva o valné hromadě konstatovala, že teprve po druhé světové válce se finanční podpora státu podstatně zvýšila. Např. ministerstvo průmyslu věnovalo 950000 Kčs, ministerstvo výživy 100000 Kčs a ministerstvo zemědělství 20000 Kčs. Valné hromady se zúčastnili za ministerstvo průmyslu JUDr. Karel Štastný. Ministr průmyslu Bohumil Laušman byl jednomyslně zvolen čestným předsedou svazu. ${ }^{78}$

Po únoru 1948 zvládl spolek i prověřování své činnosti. Dne 19. dubna 1948 oznámil Ústřednímu národnímu výboru (ÚNV) hl. m. Prahy kromě složení předsednictva a výboru svazu také, že dne 27. února 1948 byl ustaven akční výbor a jeho složení bylo nahlášeno Ústřednímu akčnímu výboru Národní fronty 5. března 1948 (čj. 10430/1948). Předsedou byl Václav Hubač (předseda spolku) za KSČ, 1. místopředseda Alois Čermák (tajemník spolku) za ROH, 2. místopředseda Josef Lanzendörfer (účetní spolku) za sociální demokracii, zapisovatelka Marie Sedláčková (úřednice časopisu) a členové JUDr. Václav

\footnotetext{
71 AMP, f. SK, sign. VIII/411, k. 285, čj. 10432/1946.

72 ANTM, f. ÚSČVB, k. 1, Korespondence o změně stanov 1945-1948.

73 [Tamtéž].

74 [Odklad valné hromady 1945: 31].

75 [Práce a vynálezy 1946: obálka].

76 [Práce a vynálezy 1946: 143].

77 [XVI. Valná hromada Svazu vynálezců v Praze 1946: obálka].

78 [Tamtéž].
} 
Srba (jednatel spolku), právní odborník, Ing. A. Stoy (náhradník člena výboru), patentový inženýr, Rudolf Štechmiler (člen výboru), redaktor svazového časopisu, Helena Dokonalová, důvěrnice zaměstnanců a František Loos (2. místopředseda spolku), tiskový referent. Dokument nepopisuje další činnost akčního výboru. ${ }^{79}$

Dne 19. dubna 1949 předložil svaz ministerstvu vnitra upravené stanovy. V původním dopise podepsaném jednatelem dr. Srbou se konstatuje, že dne 23. září 1948 projednal s příslušným referentem jednatel připomínky. Nově upravené stanovy byly schváleny valnou hromadou 5. prosince 1948. ${ }^{80}$ Nakonec vzal spolek zpět své podání z 31. srpna 1945 o změně stanov, a to dopisem 18. února 1947, a trvá dle stanov vzatých na vědomí výnosem ze dne 12. listopadu 1941 čj. D-3111-21/3-1941-6. ${ }^{81}$

Návrh poválečných stanov můžeme označit za velmi těžkopádný a nepřehledný a úkoly svazu za ambicióznější než před válkou. Řádnými orgány svazu byla valná hromada a správní výbor, širší výbor (správní výbor, náhradníci, předsedové odborů sekcí a podniků), pověřenci a komise (čl. XI). ${ }^{82}$ Podle čl. XIII volila valná hromada čestného předsedu (nahradil původně uvažovaného protektora) a náměstky, čestné předsednictvo, čestný výbor, čestné členy, čestného předsedu (nahradil původně uvažovaného prezidenta) a jeho náměstky, presidium (nahradilo původně uvažovanou velkou radu svazu, kterou tvořili členové předsednictva a presidia, zástupci institucí a korporací, odborníků) a správní výbor (předsedu, tři místopředsedy, dva jednatele, zapisovatele, případně jednoho přísedícího předsednictva). ${ }^{83}$

Svaz vynálezců po druhé světové válce (1945-1949) pokračoval ve vydávání periodika Práce a vynálezy jako ročník I., resp. XIII.-IV., resp. XVI. Odpovědným redaktorem se stal Rudolf Štechmiler. V prvním poválečném čísle se v redakčním úvodníku časopis přihlásil ke svému účelu: „Chceme a budeme podporovati jakoukoli kladnou činnost vynálezeckou a badatelskou, budeme soustavně informovati o nových závažných vynálezech a objevech domácích i cizích." 84 Současně časopis kladl důraz na podporu vynálezců a vědeckých badatelů samotných. ${ }^{85}$ Časopis organizoval různé soutěže, jako o nejlepší vědeckou knihu roku, podpora dvouletky. Původní časopis byl úzce spolkový, od nového ročníku 1945 se stal vskutku masovým. První poválečné číslo v nákladu 5000 výtisků, druhé již v 10000 výtisků, na konci prvního ročníku již 20000 výtisků. ${ }^{86} \mathrm{~V}$ rámci úvah o státní podpoře stávajících a plánovaných nových vědeckých institucí si svaz vytyčoval také své pole působnosti. „Když vědecká část plánované výstavby vědeckých výzkumných ústavů bude ve státní správě, pak je nanejvýš oprávněno, aby vynálezectví bylo ve své praktické části soustředěno při Ústředním svazu čsl. vynálezců a badatelů, o jehož potřeby by bylo ze státních prostředků důstojně a velkoryse hospodářsky postaráno, aby mohl plniti svůj úkol a nedošlo k emigraci vynálezců, které pak posilují cizí konkurenci na náš úkor." ${ }^{\text {"7 }}$

\footnotetext{
79 AMP, f. SK, sign. VIII/411, k. 285, čj. 16225/1948.

80 ANTM, f. ÚSČVB, k. 1, Korespondence o změně stanov 1945-1948.

81 AMP, f. SK, sign. VIII/411, k. 285, čj. 7612/47.

82 ANTM, f. ÚSČVB, k. 1, Rukopis Stanov Ústředního svazu československých vynálezců a badatelů v Praze, došlo 7. záríi 1945, čj. 1055/1945.

83 [Tamtéž].

84 [Co chceme? 1945: 1].

85 [Tamtéž].

86 [Do druhého ročníku 1946: obálka].

87 [Osten 1945: 101].
} 
Svaz musel být po druhé světové válce populární, když jeho tajemník apeloval na čtenáře, aby mu adresovali smysluplné žádosti. „Neobracejte se na nás s bolestmi, které byste měli tlumočiti svým poslancům nebo příslušným úřadům. Nejsme ani Pracovní úřad, ani soud, ani Hospodářská rada ČSR, ani bytový úřad, ani ústav pro osudem postižené, ani chudinská zaopatřovna, ani policie, ani reklamní kancelář, ani záložna a ani škola pro zpozdilé." 88 Ve druhém poválečném ročníku se časopis Práce a vynálezy chlubil, že si jako první československý časopis zřídil filiální redakci i administraci v největším městě USA (New Yorku) a vydává obsáhlou anglickou přílohu pro zahraniční vydání.

Jistým (až růžovým) příslibem do budoucna se stalo uzavření smlouvy ze dne 21. února 1947 mezi Rudolfem Štechmilerem, redaktorem (Praha, Zátiší 29) a Marií Svobodovou, majitelkou penzionu „Maryša“v Trenčianských Teplicích (Praha, Dlouhá 33). R. Štechmiler na základě smlouvy se svazem vydával měsíčník Práce a vynálezy. M. Svobodová se stala tichým společníkem vkladem 120000 Kčs v hotovosti.

Poúnorové koncentrace se nevyhnuly ani Svazu vynálezců, do kterého v roce 1949 vstoupil Klub moravsko-slezských vynálezců v Ostravě. Svaz uvažoval o zřízení slovenské filiálky v Bratislavě. ${ }^{99} \mathrm{~V}$ roce 1949 na valné hromadě Svazu vynálezců byla přijata rezoluce, která vyzývala k založení celostátního svazu vynálezců, dále k úzké spolupráci s Ústavy pro zvelebování živností a ke koordinaci vrcholných úřadů státní správy, ÚRO a dalších zainteresovaných institucí za účasti práce Svazu vynálezců. ${ }^{90}$

Osmého listopadu 1949 je datován dopis svazu o činnosti Krajskému velitelství SNB. V dopise svaz uvedl, že po válce překročil úzké hledisko stavovských zájmů a jeho technická kancelář levně zpracovávala patentové přrihlášky členů a zdarma poskytovala technickou pomoc i nečlenům. Získal státní subvence, podílel se na osnově zákona o podpoře lidového vynálezectví spolu s ministerstvem průmyslu a předvídala se přeměna spolku ve veřejnoprávní instituci. Osnova zákona však nebyla předložena parlamentu. Časopis Práce a vynálezy vychází v masovém nákladu 20000 výtisků a svaz čítá 2082 členů. ${ }^{91}$

„Cesta“ do Národního technického muzea dostala reálnější obrysy v roce 1949, kdy se Práce a vynálezy staly současně i časopisem muzea. ${ }^{92}$ Spolek se dle usnesení XVIII. řádné valné hromady dne 25. května 1950 začlenil do Spolku Technického musea, ${ }^{93}$ od 1. ledna 1951 státního Národního Technického muzea. Rudolf Štechmiler se v roce 1950 stal pracovníkem muzea, nebot zde vznikla odborná skupina výzkumnictví začleněním spolku do muzea. ${ }^{94}$ Správní výbor předložil návrh na začlenění do spolku NTM, přijal jeho stanovy a v jeho rámci vytvořil odbornou skupinu „Výzkumnictvi“ 95 přesněji „Vědecký pokrok a vynálezy“.

Národní technické muzeum, resp. odborná skupina Vědecký pokrok a vynálezy na vyzvání Ústředního národního výboru z 13. prosince 1950 ohledně spolku v odpovědi ze

88 [Malý 1945: 151].

89 [Svaz vynálezců a časopis Práce a vynálezy před novými úkoly 1949: 129].

90 [Práce a vynálezy 1949: obálka].

91 AMP, f. SK, sign. VIII/411, k. 285, čj. 57 632/4-V/4 1949.

92 [Svaz vynálezcu a časopis Práce a vynálezy před novými úkoly 1949: 129].

93 AMP, f. SK, sign. VIII/411 <http://amp.bach.cz/pragapublica/permalink?xid=ED0A32EF2D3411E0823D00166 F1163D4\&scan $=1>$ [7. 8. 2015].

94 [Honzáková 1972].

95 AMP, f. SK, sign. VIII/411, k. 285, čj. 262 560/9 1951, Zápis XVIII. řádné valné hromady Svazu vynálezců, konané dne 25. května 1950 o 19. hodině ve Slovanském domě v Praze. 
dne 27. prosince 1950 uvedla, že v květnu 1945 vyhořely spolkové místnosti a byl „zničen veškerý majetek svazu a zejména obsáhlá odborná knihovna“. Po válce spolek obdržel subvence ministerstva průmyslu, které jmenovalo dozorčího úředníka (do srpna do 1948). V rámci NTM se spolek jako odborná skupina má zaměřit na: „1. Shromaždování významnějších památek na československé vynálezce. 2. Bezplatnou poradenskou činnost pro vynálezce a zlepšovatele. 3. Bezplatné půjčování odborné literatury z knihovny Národního technického musea. 4. Pořádání výstav nových čs. vynálezů a technických výstav vůbec. "96

Samotné ministerstvo vnitra vydalo 2. srpna 1951 přípis ohledně Svazu vynálezců. $\mathrm{V}$ evidenci ministerstva totiž stále figuroval jako spolek. Naposledy odsouhlasené stanovy byly schváleny zmíněným výnosem ministerstva vnitra 12 . listopadu 1941 . V roce 1950 oznámil spolek změnu stanov, ale v souvislosti s reorganizací technických spolků nebyla změna projednána. V roce 1951 však vznikl Ústřední klub techniků a zlepšovatelů při ROH. Předpokládalo se, že se spolek zapojí do tohoto klubu. Pozoruhodné je další vyjádření ministerstva vnitra: „Podle sdělení $\mathrm{ROH}$ zástupci spolku vyhýbající se začlenění a pokračují dále ve své činnosti, která v prvé řadě slouží zištným zájmům jednotlivců a není zaměřena na zlepšení průmyslové výroby, jak tomu právě má napomáhati Ústřední klub techniků a zlepšovatelů.“ Spolek změnu neoznámil. „Spolek Technického musea je pak veden osobami, které naprosto neskýtají záruku vedení spolku ve směru nynějšího politického a hospodářského vývoje. Žádáme proto, aby ve spolku Národního technického musea byla provedena revise hospodaření se jměním spolku, provedeno přezkoušení spolehlivosti vedoucích funkcionářů a zjištěn poměr, $v$ jakém je nyní $\mathrm{k}$ tomuto spolku dřivější spolek Svaz vynálezců. Zjistěte zároveň poslední známé funkcionáře spolku Svazu vynálezců a zavedite proti nim řízení pro porušení spolkových předpisů tím, že provedli včlenění spolku, aniž tuto okolnost hlásili příslušným spolkovým úřadům. Funkcionáře spolku je nutno vyzvati, aby prokázali svůj správný postoj k technickému zlepšení výroby a tím $\mathrm{k}$ budovatelskému úsilí všech pracujících včleněním své organisace do Ústředního klubu techniků a zlepšovatelů při ROH. " ${ }^{97}$ Poslední věta je asi klíčem k pochopení, co vadilo na začlenění spolku do NTM.

ÚNV pak 12. září 1951 nařídil: „V rámci prováděné prověrky činnosti spolku jest nutno zjistiti i postoj funkcionářů k lidově demokratickému zř́zení a zda skýtají záruku, že činnost spolku za jejich vedení bude přispívati k budování socialismu v naší lidově demokratické republice.“ V př́padě Václava Hubáče [správně Hubač - I. J.] ONV v Praze 9 odpověděl, že jmenovaný má pověst „celkem dobrou“.98 Po únoru vstoupil do KSČ. Předtím národní socialista. Nyní je nemocný a jeho postoj k lidově demokratickému zřízení je kladný. ${ }^{99}$ Dalším prověřovaným byl JUDr. Václav Srba. ONV Praha 1 odpověděl, že jmenovaný pracuje jako soustružník v Tatra-Smíchov, má pověst dobrou. Manželka je úřednicí u Pražské spořitelny. Dcera studuje přírodovědeckou fakultu UK (ČSM), syn je v pionýru. Nejsou známky smýšlení proti lidově demokratickému zřízení. ${ }^{100}$ Obdobně sděloval ONV Praha 7, že Rudolf Štechmiler má žádoucí kladný vztah. ${ }^{101}$

\footnotetext{
${ }^{96}$ AMP, f. SK, sign. VIII/411, k. 285, čj. 267a 646/18 1950, zpráva z 27. prosince 1950.

${ }^{97}$ AMP, f. SK, sign. VIII/411, k. 285, čj. 262-1077/8 1951.

${ }^{98}$ AMP, f. SK, sign. VIII/411, k. 285, čj. 6160/51.

${ }^{99}$ AMP, f. SK, sign. VIII/411, k. 285, čj. 262-1100/18 1951.

100 AMP, f. SK, sign. VIII/411, k. 285, čj. 262-1096/5 1951.

${ }^{101}$ AMP, f. SK, sign. VIII/411, k. 285, čj. 262-1092/18 1951.
} 
V roce 1952 byla vypracována Zpráva o výsledku hospodářsko-finanční revize spolku. ${ }^{102}$ Jako př́loha č. 12 je Usnesení poslední výborové schůze likvidujícího správního výboru bývalého Svazu vynálezců, konané dne 13. listopadu 1951 v bývalých místnostech spolku. V ní se uvádí, že písemnosti technického rázu budou předány Archivu NTM, běžící patentová dokumentace patentové kancelári Ing. Stoy a Ing. Lášek, Praha II a Ing. Dr. V. Verunáč, Praha XIX. Knihovna byla již v roce 1950 věnována NTM. Výbor schválil účet rozvážný ke dni likvidace, 30. záŕí 1951, vykazující ztrátu z minulých let 146505,94 Kčs a ztrátu běžného roku ve výši 82 608,85 Kčs. Na likvidační práce bylo preliminováno 29756 Kčs. Revizní komise konstatovala, že správným zařazením položek do ztrát a zisku nebude spolek zadlužen ve výši 173 537,55 Kčs, ale naopak vykáže majetek ve výši 55 356,40 Kčss. ${ }^{103} \mathrm{~V}$ závěru komise uvedla, že ztráta běžného roku je nižší, nebot nebyly správně odděleny účty Svazu vynálezců a spolku NTM a maximálně by činila 27 218,65 Kčs. ${ }^{104}$ Náklady na likvidaci se revizní komisi zdály př́liš vysoké. ${ }^{105}$ Zpráva nedošla k žádným závěrům, že by došlo vyjma uvedených nedostatků k hrubému porušení finanční kázně, řečeno moderním jazykem.

Na tomto základě byla přezkoumána spolehlivost předních činitelů spolku a provedena finanční kontrola. Všechna obvinění se ukázala jako lichá. Pravděpodobným spouštěčem bylo renomé spolku, který nechtěl vplynout do nové struktury navázané na ROH. Přestože nemůžeme posoudit všechny pohnutky, proč spolek zaměřený na aktivní praktickou činnost usiloval stát se součástí technické muzejní instituce. Je však možné, že to souviselo i s dobovým poněkud jiným zaměřením zvláště technických muzeí, která nebyla koncipována jako přehlídka artefaktů minulosti, ale místem studia, konzultací pro soudobý vývoj. Současně asi hrála roli skutečnost, že členy spolku včetně jeho představitelů byly významné osobnosti technického i netechnického světa, včetně podnikatelů a drobných živnostníků. Přeměna spolku na státní instituci - NTM - pravděpodobně ukončila tuto akci.

O poválečné přednáškové činnosti nepřinášejí zachované dokumenty př́liš̌ informací. Např. dne 5. prosince 1948 se konala valná hromada s přednáškou Ing. Karla Bačkovského, vrchního odborového rady ministerstva průmyslu, s názvem Vynálezy a kultura. ${ }^{106}$

Po válce funkci předsedy zastával Karel F. Kříž (od 1945 do rezignace 1947) a Václav Hubač (1947-1950), funkci 1. místopředsedy Antonín Kasýk (od 1945 do rezignace 1947), Jiř́ Janoušek (1947-1948), Ing. Artur Stoy (1948-1950), JUDr. Václav Srba (1950), funkci 2. místopř̀edsedy pak Václav Kracík (1945-1947, úřadující místopředseda 1947), František Loos (1947-1950) a Ing. František Rott (1950).

\section{Členská základna}

Na vedoucích místech spolku se v představenstvu (předseda, místopředsedové, jednatel, pokladník a účetní) vystř́ídala řada významných odborníků, at již se jednalo o zaměstnance ve vysoké manažerské funkci či úředníky ve státní správě (ministerstva, Zemský soud), státních podnicích (ČSD), „polostátních“ institucích, jako obchodní a živnostenské

\footnotetext{
${ }^{102}$ AMP, f. SK, sign. VIII/411, k. 285, čj. 262-107/18 1952, Zpráva o výsledku hospodářsko-finanční revize 1952. 103 [Tamtéź: 33].

104 [Tamtéž: 35].

105 [Tamtéž: 36].

${ }^{106}$ AMP, f. SK, sign. VIII/411, k. 285, čj. 47016/1948.
} 
komoře v Praze, či šlo o ředitele Technického musea v Praze, z privátní sféry ředitele podniků, podnikatele, lékaře, prokuristy, technické úředníky, administrativní zaměstnance, kvalifikované dělníky, krejčí, často s vysokoškolským titulem (Ing.) apod.

Přestože bylo výše zmíněno, že Svaz vynálezců disponoval velkou členskou základnou a v roce 1926 dosáhl tento počet výše jednoho tisíce, nemáme úplné ani zcela spolehlivé údaje o představenstvu svazu a výboru, stejně jako o členech svazu. Rekonstrukce vedení Svazu vynálezců je uvedena v prŕloze příspěvku. Přestože máme k dispozici tři svého druhu kartotéky, není možné rekonstruovat úplný stav členské základny Svazu. V Seznamu členů 1929-1946 ${ }^{107}$ napočítáme 1491 členů, z toho z období 1920 - 15. března 1939 jen 50, pro období protektorátu 512 členů, pro období od 8./9. května 1945 dokonce 697 členů a 232 členů bez udání data vzniku členství. Členy (členky jen zcela výjimečně) bychom nalezli podle uvedeného bydliště v celém Československu, byt údaje o slovenských členech jsou zachovány až po roce 1945 (celkem 32 členů). A sedm členů uvedlo bydliště v zahraničí (Německo, Rakousko aj.). Další neúplná kartotéka ${ }^{108}$ vykazuje jen 430 členů. Mezi nejpočetnější profesní skupinu patřili úředníci (techničtí, zemědělští a administrativní; celkem 90 členů), obchodníci (23 členů), zámečníci (strojní aj.; 16 členů) a studující (16 členů). Jinak nalezneme mezi členy v podstatě všechny pracovní pozice, a to od praktických povolání (dělník, nástrojař, dílovedoucí, konstruktér, mechanik, technik, klavírní technik) přes živnostenská (hostinský, krejčí, drogista) k ryze humanitním (učitel, hudební skladatel). Kartotéka členů svazu podle členských čísel ${ }^{109}$ vykazuje 623 členů. Podle zpráv uvedených ve spolkovém časopise Práce a vynálezy v roce 1926 se tisícím členem stal František Kubec z Vamberka. Jednalo se tedy o velký zájmový spolek. Neúplné kartotéky vyjma zničení v květnu 1945 vyvolávají také otázku možných skartací, zejména předválečných členů a současně potvrzují zájem o členství po druhé světové válce. Členy byli až na výjimky jednotlivci, z kolektivních členů uved’me Jednotu k povzbuzení průmyslu v Čechách či Československou obchodní komoru ve Vídni.

\section{Závěr}

Svaz vynálezců byl aktivní a úspěšný v rámci mantinelů, ve kterých se jako zájmový spolek pohyboval. Svým dosahem (členskou základnou) oslovoval nejen zájemce v nejširším smyslu slova o vědu a techniku (amatérské kutily, konstruktéry profesionály, čtenáře) v Praze, ale i v jiných regionech Československa. Ve třicátých letech skomírající ústřední časopis Věda a vynálezy začal po druhé světové válce vzkvétat a jako součást periodika Svět techniky přetrval ještě další dvě desetiletí. Po válce nastal velký př́liliv nových členů. Svazu vynálezců patří důstojné místo vedle takových institucí jako Masarykova akademie práce či Jednota pro povzbuzení průmyslu v Čechách. Dokonce v jistém ohledu Svaz suploval státní zájem a podporu inovační techniky. Ostatně informační a osvětová činnost svazu je z publikovaných zpráv zřejmá. Svazu se nepodařilo v meziválečném období získat trvalejší, zejména finanční podporu ze strany státu či dalších významných institucí. Z výzev průběžně uveřejňovaných na stránkách časopisu je zřejmé, že platební morálka členů svazu

${ }^{107}$ ANTM Praha, f. Ústřední svaz československých vynálezců a badatelů, (dále jen ÚSČVB), k. 1, Seznam členů 1920-1946.

${ }^{108}$ ANTM Praha, f. ÚSČVB, k. 2, Kartotéka členů abecední.

${ }^{109}$ ANTM Praha, f. ÚSČVB, k. 2, Kartotéka členů dle čl. čísel. 
nebyla př́liš vysoká. Tak pochybnosti ze strany státu či společenských organizací ohledně údajné neloajálnosti spolku a jeho předsednictva či finančních machinací se neprokázala. Spolek ustál tlak ROH na začlenění do Ústředního klubu techniků a zlepšovatelů a zvolil cestu do Národního technického muzea. Autor si je vědom, že další možné informace o svazu a jeho činnosti mohou být rozptýlené i v dalších archivech a fondech a lze naše znalosti průběžně doplňovat a zpřesňovat. Činnost Svazu vynálezců by neměla být zapomenuta a měl by se vrátit na historické jeviště, kam právem patř́i.

\section{Archivní prameny}

Archiv hl. m. Prahy (AMP), fond Spolkový katastr (SK), sign. VIII/411, karton 285, čj. 262 560/9 1951. AMP, SK, sign. VIII/411, karton 285, čj. 17411/1943.

AMP, SK, sign. VIII/411, karton 285, čj. 8-A 1334/1920.

AMP, SK, sign. VIII/411, karton 285, čj. 11601 s II a čj. 8A-1334-43 106 (7250 S II). <http://amp.bach .cz/pragapublica/permalink?xid=ED0A32EF2D3411E0823D00166F1163D4\&scan=1 $>$ [cit. 7. 8. 2015]. AMP, SK, sign. VIII/411, karton 285, čj. 7250/1920, Stanovy Svazu vynálezců, rkp. s. 1-7.

AMP, SK, sign. VIII/411, karton 285, čj. 16802/1922, Stanovy Svazu vynálezců, rkp.

AMP, SK, sign. VIII/411, karton 285, čj. 5003/1927.

AMP, SK, sign. VIII/411, karton 285, čj. 20925/1930, Stanovy svazu vynálezců v Praze.

AMP, SK, sign. VIII/411, karton 285, čj. 11 601/1920 a 10 757/1920.

AMP, SK, sign. VIII/411, karton 285, čj. 5077/1924.

AMP, SK, sign. VIII/411, karton 285, čj. 11 040/1920.

AMP, SK, sign. VIII/411, karton 285, čj. 2 938/1935 a 7 681/1935.

AMP, SK, sign. VIII/411, karton 285, čj. 810/1935.

AMP, SK, sign. VIII/411, karton 285, čj. 9 299/1935.

AMP, SK, sign. VIII/411, karton 285, čj. 24 530/1937.

AMP, SK, sign. VIII/411, karton 285, čj. 24 530/1937, protokol bez čj.

<http://aleph.nkp.cz/F/JK8Q58SMPS9CNKQTVGE7MX4MPY62MLEY7EASH286UNAMG8YNP5

-49647 ?func $=$ full-set-set\&set_number $=047638 \&$ set_entry $=000002 \&$ format $=999 \#$ tail $>$ [cit. 23. 7. 2015].

AMP, SK, sign. VIII/411, karton 285, čj. 7773/1939.

AMP, SK, sign. VIII/411, karton 285, čj. 13966/1939.

AMP, SK, sign. VIII/411, karton 285, čj. 253/13 1940.

AMP, SK, sign. VIII/411, karton 285, čj. 253/13 1940 a čj. 113/1942.

AMP, SK, sign. VIII/411, karton 285, Stanovy, sine čj.

AMP, SK, sign. VIII/411, karton 285, čj. 21 598/1940.

AMP, SK, sign. VIII/411, karton 285, čj. 22 562/1940 priora 21 598/1940.

AMP, SK, sign. VIII/411, karton 285, čj. 7250/1941, rkp. s. 1-3.

AMP, SK, sign. VIII/411, karton 285, čj. 7250/1941, Protokol sepsaný na policejním ředitelství v Praze dne 24. března 1941, sine čj.

AMP, SK, sign. VIII/411, karton 285, čj. 7250/1941.

AMP, SK, sign. VIII/411, karton 285, čj. 10432/1946.

AMP, SK, sign. VIII/411, karton 285, čj. 16225/1948.

AMP, SK, sign. VIII/411, karton 285, čj. 7612/47.

AMP, SK, sign. VIII/411, karton 285, čj. 57 632/4-V/4 1949.

AMP, SK, sign. VIII/411, karton 285, čj. 262 560/9 1951, Zápis XVIII. řádné valné hromady Svazu vyná-

lezců, konané dne 25. května 1950 o 19 hodině ve Slovanském domě v Praze.

AMP, SK, sign. VIII/411, karton 285, čj. 267a 646/18 1950, zpráva ze 27. prosince 1950.

AMP, SK, sign. VIII/411, karton 285, čj. 262-1077/8 1951.

AMP, SK, sign. VIII/411, karton 285, čj. 6160/51.

AMP, SK, sign. VIII/411, karton 285, čj. 262-1100/18 1951.

AMP, SK, sign. VIII/411, karton 285, čj. 262-1096/5 1951. 
AMP, SK, sign. VIII/411, karton 285, čj. 262-1092/18 1951.

AMP, SK, sign. VIII/411, karton 285, čj. 262-107/18 1952, Zpráva o výsledku hospodářsko-finanční revize 1952.

AMP, SK, sign. VIII/411, karton 285, čj. 47016/1948.

Archiv Národního technického muzea (ANTM Praha), fond Ústřední československých vynálezců a badatelů (ÚČSVB), karton 1, Stanovy svazu vynálezců v Praze. Založeno r. 1920, Praha 1937. Dodatek Usnesení valné hromady Svazu vynálezců z 5. prosince 1937.

ANTM Praha, ÚČSVB, karton 1, Stanovy Svazu vynálezců v Praze.

ANTM, ÚSČVB, karton 1, Korespondence o změně stanov 1945-1948.

ANTM, ÚSČVB, karton 1, Rukopis Stanov Ústředního svazu československých vynálezců a badatelů v Praze, došlo 7. záŕí 1945, čj. 1055/1945.

ANTM Praha, ÚSČVB, karton 1, Seznam členů 1920-1946.

ANTM Praha, ÚSČVB, karton 2, Kartotéka členů abecední.

ANTM Praha, ÚSČVB, karton 2, Kartotéka členů dle čl. čísel.

Národní archiv Praha (NA Praha), fond Ministerstvo průmyslu, obchodu a živností (MPOŽ), karton 1013, čj. $114779 / 36$ priora $71946 / 36$.

NA Praha, MPOŽ, karton 1013, čj. 71946/36, Stanovy Svazu vynálezců v Praze.

NA Praha, fond Presidium ministerské rady (PMR), karton 1431, čj. 45523/40.

Politisches Amt des Auswärtigen Amtes, Berlin, Prag, karton 236, čj. X/2bc/1935.

Státní oblastní archiv Praha (SOA Praha), fond Obchodní a živnostenská komora Praha (OŽK Praha), karton 775, sl. VI/1/14, čj. 41172/1926.

\section{Literatura}

Akce pro zabezpečení našich vynálezců a badatelů [1946]. Práce a vynálezy 1/13 (4): obálka.

Co chceme? [1945]. Práce a vynálezy 1/13 (1): 1.

Do druhého ročníku [1946]. Práce a vynálezy 2/14 (1): obálka.

Holan, J. E. [1923-1924]. Zpráva o činnosti a budoucích úkolech Svazu vynálezců a badatelů v Praze. Práce a vynálezy 4 (2): $1-2$.

Holan, J. E. [1923-1924]. Zpráva o činnosti a budoucích úkolech Svazu vynálezců a badatelů v Praze. Práce a vynálezy 4 (3): 28-29.

Honzáková, Valérie [1972]. Ústřední svaz čs. Vynálezců a badatelů ((1920) 1945-1950). Prozatímní inventární seznam. Praha: NTM. Ev. č. 197.

Malý. J. [1945]. Některým našim dopisovatelům. Práce a vynálezy 1/13 (6-7): 151.

Nová adresa Svazu vynálezců [1945]. Práce a vynálezy 1/13 (1): 31.

Odklad valné hromady [1945]. Práce a vynálezy 1/13 (1): 31.

Osten, Vlastimil [1945]. Nebezpečí emigrace vynálezů. Práce a vynálezy 1/13 (5): 101.

Patentní věstník [1921-1922]. Praha: Patentní úřad.

Práce a vynálezy [1920-1921] 1 (1): obálka.

Práce a vynálezy [1922-1923] 3 (1): obálka.

Práce a vynálezy [1946] 1/13 (6-7): obálka.

Práce a vynálezy [1946] 2/14 (4-5): 143.

Práce a vynálezy [1949] 4/16 (1): obálka.

Schůze vynálezců a majetníků patentů [1922-1923]. Práce a vynálezy 3 (7-8): 97-98.

Svaz vynálezců a časopis Práce a vynálezy před novými úkoly [1949]. Práce a vynálezy 4/16 (9): 129.

XVI. Valná hromada Svazu vynálezců v Praze [1946]. Práce a vynálezy 2/14 (6-7): obálka.

Štěpánek, František [1920-1921]. Význačné nové české vynálezy. Práce a vynálezy 1 (2): 17-18.

Štěpánek, František [1921-1922]. Svazy vynálezců v cizině a u nás. Práce a vynálezy 2 (1): 1-4.

Štěpánek, František [1921-1922]. Svazy vynálezců v cizině a u nás. Práce a vynálezy 2 (2): 24.

Zimmler, Emil [2013]. Moje inženýrské paměti. 2 díly. Praha: NTM, Scriptorium, Město Nymburk. 
Ivan Jakubec (*1960) působí na Ústavu hospodářských a sociálních dějin Filozofické fakulty Univerzity Karlovy. Odborně se zabývá moderními hospodářskými dějinami 19.-20. století, dèjinami techniky, dopravy a infrastruktury. 